\title{
Transformasi nilai Sabilulungan dalam aktivitas komunikasi pelayanan publik di Pemerintahan Kabupaten Bandung
}

\author{
Heru Ryanto Budiana ${ }^{1}$, Atwar Bajari², Rahman Mulyawan ${ }^{3}$ \\ ${ }^{1,2,3}$ Universitas Padjadjaran, Bandung, Indonesia
}

\begin{abstract}
ABSTRAK
Nilai kearifan lokal Sabilulungan dijadikan sebagai landasan penyelenggaraan Pemerintah di Kabupaten Bandung. Selain untuk menjaga nilai budaya Sabilulungan sebagai salah satu warisan budaya Sunda, Sabilulungan juga memiliki nilai yang dapat diterapkan pada setiap aktivitas Pemerintahan agar berlangsung dengan baik. Salah satunya adalah aktivitas komunikasi pelayanan publik. Untuk itu penelitian ini dilakukan untuk mengetahui bagaimana Transformasi nilai kearifan lokal sabilulungan dalam aktivitas komunikasi pelayanan publik di Pemerintah Kabupaten Bandung. Subjek penelitian ini dipilih dengan cara purposive dimana subjek dalam penelitian ini adalah aparatur Pemerintah Kabupaten Bandung. Objek penelitian ini adalah hal yang terkait dengan transformasi nilai kearifan lokal sabilulungan dalam aktivitas komunikasi pelayanan publik di Pemerintah Kabupaten Bandung pada kepemimpinan Dadang Naser. Hasil penelitian ini diantaranya adalah nilai Sabilulungan dapat dijadikan pedoman dalam pelaksanaan kegiatan Pemerintahan karena mengandung nilai moralitas didalamnya. Sabilulungan memiliki makna gotong royong, sehingga bisa ditransformasikan pada aktivitas komunikasi pelayanan publik karena dapat menjadi landasan dalam pelaksanaan untuk tercapainya sinergitas dan empati yang merupakan bagian penting dari pelayanan publik. Sabilulungan juga dapat membantu tercapainya komunikasi yang efektif dimana semua pihak dapat menerima pesan yang hendak disampaikan oleh Pemerintah Kabupaten Bandung. Dalam pelaksanaannya nilai Sabilulungan belum sepenuhnya dipahami dan diterapkan sehingga diperlukan upaya-upaya untuk mengoptimalkan nilai Sabilulungan. Peneliti menyarankan salah satu inovasi yang bisa diterapkan agar lembaga Pemerintah dapat mengoptimalkan transformasi nilai kearifan lokal yakni dengan menggunakan kemajuan teknologi khususnya media internet didalamnya media sosial agar seluruh aspek pemerintah juga masyarakat dapat mewujudkan tujuan dari pelayanan publik yakni tercapaikanya kesejahteraan masyarakat.
\end{abstract}

Kata-kata Kunci:Komunikasi; pelayanan publik; transformasi; nilai kearifan lokal; pemerintahan

\section{Transforming Sabilulungan values in public service communication activities in Bandung Regency Government}

\begin{abstract}
The value of Sabilulungan's local wisdom is used as a foundation for the administration of the Government in Bandung Regency. In addition to maintaining the cultural value of Sabilulungan as one of the Sundanese cultural heritage, Sabilulungan also has values that can be applied to every Government activity so that it takes place properly. One of them is public service communication activities. For this reason, this research was conducted to find out how the transformation of sabilulungan local wisdom values in public service communication activities in the Government of Bandung Regency. The subject of this research was chosen by the purposive method in which the subjects in this study were the Bandung District Government Apparatus. The object of this research is something related to the transformation of the value of sabilulungan local wisdom in the activities of public service communication in the Bandung Regency Government under the leadership of Dadang Naser. The results of this study include the value of Sabilulungan can be used as a guide in the implementation of Government activities because it contains moral values in it. Sabilulungan has the meaning of cooperation so that it can be transformed into public service communication activities because it can be the foundation in the implementation of achieving synergy and empathy which is an important part of public service. Sabilulungan can also help achieve effective communication where all parties can receive messages to be conveyed by the Bandung Regency Government. In its implementation, the value of Sabilulungan is not fully understood and applied so that efforts are needed to optimize the value of Sabilulungan. Researchers suggest one of the innovations that can be applied so that Government institutions can optimize the transformation of local wisdom values by using technological advancements, especially internet media, in which social media so that all aspects of government and society can realize the goals of public service, namely the achievement of public welfare.
\end{abstract}

Keywords: Communication; public service; transformation; value of local wisdom; government

Korespondensi: Heru Ryanto Budiana. Universitas Padjadjaran. Jl. Raya Bandung-Sumedang Km. 21 Jatinangor, Sumedang, Indonesia 45363. No.Email: heru.ryanto@unpad.ac.id 


\section{PENDAHULUAN}

Petikan lirik lagu Sabilulungan ciptaan Koko Koswara atau yang dikenal dengan nama panggilan Mang Koko di atas menjadi inspirasi bagi Dadang Mochammad Naser atau biasa dipanggil Kang Daser menggunakan istilah Sabilulungan sebagai slogan pada masa kampanye pemilihan Bupati, baik pada periode pertama maupun periode kedua.

Seiring terpilihnya beliau menjadi pimpinan daerah Kabupaten Bandung, maka sejak tahun 2010, Sabilulungan dijadikan sebagai motto dalam penyelenggaraan roda pemerintahan di Kabupaten Bandung. Menjadikan Sabilulungan sebagai motto, tidak terlepas dari upaya Kang Daser mengimplementasikan nilai-nilai luhur kehidupan Sunda yang terdapat dalam konsep Sabilulungan sebagai pijakan dalam mewujudkan pelayanan publik di Kabupaten Bandung ke arah yang lebih baik.

Peningkatan pelayanan publik penting untuk dilakukan oleh sebuah lembaga Pemerintah. Pada prinsipnya masyarakat akan terus mengharapkan peningkatan kualitas pelayanan publik yang dilakukan oleh Lembaga Pemerintah (Alamsyah \& Fitriah, 2017). Hal ini sejalan dengan pemenuhan hak dan kewajiban masyarakat serta terwujudnya tanggung jawab Negara melalui pelayanan publik yang optimal.

Kinerja pelaku komunikasi dapat mengalami peningkatan kualitas melalui komunikasi yang efektif. Maka pelaksana pelayanan publik dalam hal ini para aparatur Pemerintah harus memiliki kemampuan untuk menggunakan pola komunikasi yang efektif agar tercapai tujuan lembaga (Budi, 2012).

Instrumen yang menentukan komunikasi efektif adalah: (1) Pemahaman penerima pesan; (2) Adanya kesenangan pada kedua pihak yang melakukan komunikasi; (3) Dapat memengaruhi sikap pihak lain;(4) Memperbaiki hubungan; dan (5) Hasil sesuai dengan tujuan berkomunikasi yang ditunjukan dengan tindakan perima pesan. Tubb \& Moss dalam (Budi, 2012).

Nilai kearifan lokal Sabilulungan di transformasi oleh Pemerintah Kabupaten Bandung dalam pelaksanaan aktivitas komunikasi publik. Sabilulungan sering dipadankan dengan pengertian gotong royong atau kerjasama (Bachrein, 2010; Adha, 2015; Guntari, 2016); termasuk juga dalam kamus Sunda-Indonesia online. Padahal menurut Kang
Daser, dalam sebuah kesempatan wawancara, mengatakan bahwa, gotong royong dalam Ki Sunda sebagai bagian dari Sabilulungan, Sabilulungan bukan hanya sekedar gotong royong, tetapi juga memiliki makna sinergitas, kebersamaan, silih asah, silih asih, silih asuh, silih pikaheman, ngaluluguan, ngakojoan (kepemimpinan yang memberikan keteladanan), juga terkandung dalam Sabilulungan nilai-nilai spiritualnya.

Nilai-nilai yang terkandung dalam makna Sabilulungan tersebut, dianggap merupakan modal sosial sebagai spirit atau ruh dalam upaya menggerakan roda Pemerintahan Daerah Kabupaten Bandung khususnya dalam dalam aktivitas komunikasi pelayanan publik.

Berbicara mengenai aktivitas komunikasi pelayanan publik, erat kaitannya dengan alur birokrasi. Penyakit dalam birokrasi adalah koordinasi antar lembaga, koordinasi antar internal lembaga dan antar sub-bagian terdapat ego sentral yang sangat kuat. Maka untuk menjalankan birokrasi tersebut dibutuhkan prinsip Sabilulungan yang bisa dijadikan jembatan agar tidak ada ego antar bagian atau divisi, terdapat rasa saling berpegangan tangan di dalam pemerintahan serta bagaimana mengikis kelemahan-kelemahan yang ada di Pemerintahan. Dengan menerapkan nilai Sabilulungan, Pemerintahan itu bisa maju, sejahtera dan optimal dalam melakukan penyejahteraan masyarakat.

Transformasi nilai Sabilulungan pada aktivitas komunikasi pelayanan publik penting untuk diterapkan sebab saat ini masih banyak masyarakat memiliki anggapan bahwa komunikasi yang terdapat pada pelayanan publik oleh Lembaga Pemerintah identik dengan birokrasi yang berbelit-belit. Hal ini dijadikan salah satu indikator masih kurangnya pelayanan Lembaga Pemerintah pada publik. Sabilulungan diharapkan dapat mengikis anggapan masyarakat yakni pelayanan publik yang dilakukan oleh Lembaga Pemerintah masih rendah (Drajat, 2008).

Tercantum dalam Road Map Reformasi Birokrasi Tahun 2015 - 2019 yang telah ditetapkan melalui Peraturan Menteri Pendayagunaan Aparatur Negara dan Reformasi Birokrasi Nomor 11 Tahun 2015, bahwa reformasi birokrasi bukan lagi sekedar tuntutan dari segenap elemen masyarakat yang mengharapkan agar birokrasi dan terutama 
aparatur dapat berkualitas lebih baik lagi baik di Kementerian/Lembaga maupun Pemerintah Daerah bagi penyelenggara pemerintahan baik kementerian maupun pemerintahan provinsi dan daerah. Keberhasilan pelaksanaan reformasi birokrasi bukan pada prosedur atau laporan saja, namun bagaimana masyarakat yang dilayani dapat merasakan dampak perubahan yang lebih baik.

Budaya organisasi tidak terlepas dari faktor kepemimpinan, sebagaimana dijelaskan dalam lampiran PermenPANRB No. 39 Tahun 2012 tersebut bahwa keberhasilan dalam mengembangkan dan menumbuh-kembangkan budayaorganisasisangatditentukanolehperilaku pimpinan organisasi. Senada dengan pendapat PermenPANRB bahwa budaya organisasi tidak terlepas dari faktor kepemimpinan, terdapat keterkaitan yang sangat erat antara budaya organisasi dan kepimpinan (Schein, 2010), yang diilustrasikan seperti "to side of the same coin" atau "dua sisi dari sekeping mata uang", untuk menjelaskan bahwa antara kepemimpinan dan budaya organisasi masing-masing mempunyai keterkaitan yang sangat erat dan hampir tidak dapat dipisahkan.

Budaya dalam sistem organisasi dapat dipahami sebagai hasil dari seorang pemimpin atau pencipta, yang menetapkan sebuah domain tertentu, yang oleh karenanya dapat diterima oleh kelompok sasaran tertentu. Pemimpin dapat dikatakan bertindak sebagai pendiri sebuah budaya, yang akan mengakomodasi peraturan, nilai, kepercayaan dan persepsi kelompok yang terlibat. Memperluas hal ini, posisi pemimpin tidak hanya menyediakan kerangka kepercayaan nilai untuk kelompok, tetapi juga struktur, keteraturan dan makna. Tentu saja, elemen budaya pemimpin mungkin tidak berfungsi dan dapat berubah sewaktuwaktu.

Tuntutan reformasi birokrasi dengan melakukan perubahan budaya kerja yang diturunkan dari budaya organisasi dan sumber nilai dapat diperoleh antara lain melalui kebiasaan yang berkembang baik dalam masyarakat atau adat sebagaimana dijelaskan diatas, memberikan ruang bagi pemerintahan daerah di Indonesia untuk menggali dan mengimplementasikan nilai-nilai kearifan lokal di daerahnya masing-masing dalam mengembangkan budaya organisasi pemerintahannya.
Selain itu adanya transformasi nilai budaya lokal pada aktivitas komunikasi budaya kerja Lembaga akan menciptakan good governance. Jika konsep good governance diterapkan, maka birokrasi yang terdapat pada proses komunikasi pelayanan publik akan berjalan efektif. Good governance akan tercipta jika dilakukan komunikasi yang efektif dimana terdapat kesesuaian antara pesan yang disampaikan dari informan kepada penerima pesan. Pada intinya, konsep good governance akan mejuwudkan kesejahteraan masyarakat melalui kesepakatan mengenai penyelenggaraan kebijakan. Susanto dalam (Alamsyah \& Fitriah, 2017)

Dalam konteks pemerintahan daerah di Indonesia saat ini terdapat beberapa nilai atau norma kearifan lokal yang dijadikan basis atau dasar nilai organisasi pemerintahan. Nilai Budaya kearifan lokal mengandung nilai moralitas yang dapat dijadikan pedoman dalam pelaksanaan Pemerintah (Mariana \& Paskarina, 2009).

Satu di antara sekian banyak kearifan lokal di Indonesia adalah kearifan lokal masyarakat Sunda. Dalam berbagai referensi sering dikatakan bahwa, kearfian lokal mencakup acuan dalam kehidupan sehari-hari yang berlaku di lingkup masyarakat tertentu. Kearifan lokal ini bersifat abstrak sekaligus juga kongkret. Pedoman-pedomannya berupa sistem yang abstrak, tetapi dalam pelaksanaannya berupa sistem yang kongkret karena menjadi alat yang digunakan dalam memperbaiki dan menyelesaikan permasalahan dalam masyarakat budaya. (Isnendes, 2014).

Walaupun kearifan lokal dianggap memiliki nilai luhur dan dapat menjadi pedoman dalam menyelesaikan permasalahan, akan tetapi tidak sedikit tantangan yang dihadapi karena perubahan cara pandang masyarakat terhadap budaya lokal yang dianggap terbelakang, sebaimana penelitian yang hasilnya menunjukkan bahwa tantangan yang dihadapi dalam menempatkan nilai kearifan lokal sunda sebagai basis tata kelola pemerintahan yang baik (good governance) ditengah terpaan arus globalisasi adalah anggapan bahwa kebijakan berbasis kearifan lokal yang diterapkan bersifat kedaerahan, kuno, tradisional, dan dianggap sebagai suatu kemunduran demokrasi karena seakan kembali pada masa lalu di era yang sudah modern (Rahmatiani, 2016).

Kabupaten Bandung mentrasnformasi 
nilai kearifan lokal budaya Sunda untuk melakukan komunikasi efektif pada aktivitas pelayanan publik. Budaya Sunda menjadi ciri khas masyarakat Sunda. Masyarakat Sunda atau Suku Sunda adalah orang-orang yang secara turun temurun menggunakan bahasa dan dialek Sunda sebagai bahasa ibu serta dialek dalam percakapan sehari-hari. Masyarakat Sunda dimaksud, tinggal di daerah Jawa Barat dan Banten yang dulu dikenal sebagai Tanah Pasundan atau Tatar Sunda. Koentjaraningrat dalam (Indrawardana, 2012).

Jawa Barat merupakan salah satu Provinsi yang kaya dengan berbagai kearifan lokal yang mengandung makna filosofis yang mendalam serta nilai (values) mulia dan adiluhur. Nilainilai luhur tersebut dapat dijadikan sebagai nilai budaya organisasi pemerintah daerah, seperti "Sabilulungan" di Pemerintah Daerah (Pemda) Kabupaten Bandung.

Penggunaan nilai kearifan lokal Sunda "Sabilulungan" sebagai budaya organisasi pemerintah daerah di Kabupaten Bandung, tidak terlepas dari kepemimpinan Bupati Dadang Mochamad Naser baik periode pertama periode tahun 2010-2015 maupun pada periode kedua tahun 2015-2020.

Sabilulungan pada awalnya merupakan istilah yang digunakan Dadang Naser sebagai slogan pada masa kampanye pemilihan Bupati, baik pada periode pertama maupun periode kedua. Pemilihan istilah kearifan lokal Sunda "Sabilulungan" tersebut tidak terlepas dari perjalanan panjang dan pengalaman Dadang Naser sebelum menjadi Bupati, khususnya ketika Dadang Naser menjadi ketua KNPI dan anggota DRPD Kabupaten Bandung.

Realitas yang tumbuh di masyarakat tersebut, khususnya di Kabupaten Bandung menginspirasi Dadang Naser untuk mengangkat "Sabilulungan" tidak hanya sebagai slogan dimasa kampanye tetapi sebagai budaya organisasi pemerintahaan di Kabupaten Bandung. "Sabilulungan" yang awalnya berarti gotong royong atau bersama-sama mengalami modifikasi nilai dan memiliki arti yang sangat luas dan dapat ditinjau dalam beragam perspektif.

Pada sebuah simposium tentang "Kearifan Lokal Sebagai Aset Bangsa Pencetak Generasi Cerdas Berkeperibadian", Oktober tahun 2016 di kampus Cibiru Universitas Pendidikan Indonesia (UPI) dengan judul pemaparannya
"Dinamika Budaya "Sabilulungan" Dalam Inovasi Pembangunan Di Kabupaten Bandung, Kang daser menyampaikan bahwa sabilulungan merupakan nilai atau karakter lokal yang hidup, tumbuh dan berkembang di masyarakat sunda, dimana karakter lokal ini akan memperkaya dan memperkokoh karakter dan budaya bangsa.

Penelurusan yang dilakukan oleh Supriyadi, Nassarudin, \& Azhar, (2017), menemukan bahwa arti Terma Sabilulungan berasal dari Bahasa Sunda tertulis dalam buku Kamus Sunda-Indonesa karya (Sumantri, 1985), terbitan Pusat Pembinaan dan Pengembangan Bahasa Depdikbud Jakarta, yang memiliki arti; seia-sekata; saling tolong. Penjelasan lebih lanjut dalam kamus tersebut, menunjukan bahwa Sabilulungan merupakan warisan lisan yang berasal dari Bahasa Sunda dan berakar kuat dari local wisdom warga Sunda di Jawa Barat. Sabilulungan dikenal sebagai nilai kearifan lokal, yang tumbuh dan berkembang dalam tradisi lisan masyarakat Sunda

Sabilulungan adalah tradisi masyarakat Sunda dengan Sabilulungan sebagai simbolnya. Kata Sabilulungan mengalami pergeseran dan perkembangan makna karena dinamika ruang dan waktu, sehingga Sabilulungan memiliki aneka ragam arti dan maksud dilihat dari berbagai perspektif. (Supriyadi et al., 2017)

Nilai budaya sabilulungan sebagaimana telah dikemukakan di atas, telah dikenal sejak lama di masyarakat Sunda. Bukan persoalan mudah bagi Dadang Naser membawa nilai kearifan lokal "Sabilulungan" yang telah tumbuh dan berkembang sejak lama di masyarakat masuk ke dalam ruang-ruang pemerintahan.

Salah satu tantangan terbesar yang dihadapi untuk melakukan transformasi nilai kearifan lokal sabilulungan dalam aktivitas komunikasi pelayanan publik di Pemerintah Kabupaten Bandung adalah pada tahap pelaksanaan yang berawal dari pemahaman para aparatur lembaga pemerintah mengenai nilai Sabilulungan. Tentu tidak belum semua pihak paham akan makna nilai Sabilulungan baik pihak yang terkait dalam pemerintahan di Kabupaten Bandung adalah urang Sunda, baik dikalangan aparatur pemerintahan, masyarakat sebagai sasaran pelayanan pemerintah maupun sektor swasta sebagai mitra pemerintahan.

Berbagai upaya dan kerja keras perlu dilakukan oleh Dadang Naser sebagai pemimpin di Pemerintahan Kabupaten Bandung yang 
mengusung Nilai "Sabilulungan" dalam Melakukan transformasi nilai kearifan lokal sabilulungan dalam aktivitas komunikasi pelayanan publik di Pemerintah Kabupaten Bandung. Hal pertama yang dilakukan adalah memastikan jika penerima pesan paham terhadap pesan yang hendak disampaikan yakni dalam hal transformasi nilai-nilai Sabilulungan. Pemahaman penerima pesan menjadi instrument pertama dalam menentukan komunikasi efektif seperti dijelaskan oleh Tubb \& Moss (Alamsyah \& Fitriah, 2017). Sejalan dengan pernyataan tersebut, Robbins \& Judge (2017) menjelaskan bahwa budaya organisasi mengacu pada suatu sistem makna bersama yang dianut oleh anggota-anggota yang membedakan organisasi tersebut dengan organisasi yang lain. sistem pemaknaan bersama tersebut merupakan seperangkat karakter kunci dari nilai-nilai organisasi.

Berdasarkan pandangan Robbins tersebut, mengembangkan budaya organisasi selain harus sesuai dengan nilai-nilai dalam masyarakatnya, sesuai juga dengan tantangan dan kebutuhan organisasinya, dan harus dimaknai bersama oleh seluruh anggota dan stakeholder dalam organisasi tersebut.

Bagaimana budaya organisasi harus dimaknai secara bersama-sama juga dikemukan oleh Schein (2010), bahwa budaya bersifat abstrak, namun kekuatan yang diciptakannya dalam kehidupan organisasi sangat kuat. Kekuatan tersebut dikarenakan budaya bekerja di luar kesadaran manusia, untuk itu sangat penting memahami budaya organisasi, bukan hanya disebabkan kekuatannya tetapi juga membantu menjelaskan pengalaman individu dalam kehidupan organisasi tersebut.

Mengimplemtasikan nilai "Sabilulungan" pada aktivitas komunikasi pelayanan publik di Kabupaten Bandung adalah sebuah pekerjaan besar dan membutuhkan komitmen serta kedisiplinan yang luar biasa, sumber daya yang besar dan waktu yang panjang.

Periode pertama kepemimpinan Dadang Naser dengan filosofi Sabilulungannya telah menunjukkan beberapa kemajuan pencapaian, antaralain;peningkatakan kondisipembangunan daerah yang dapat dianalisis melalui IPM atau Indeks Pembangunan Manusia. Dalam lima tahun kepemimpinan Dadang Naser pada periode pertama tahun 2010 - 2015, IPM Kabupaten Bandung menunjukkan peningkatan setiap tahunnya, bahkan Sebagaimana tercantum dalam Dokumen RPJMD Kabupaten Bandung Tahun 2016 - 2021, pada tahun 2015 mencapai 76,45 yang merupakan daerah dengan kecepatan peningkatan IPM nya tertinggi. Terlihat dalam gambar 1.

Komitmen Dadang Naser dalam wujudkan Nilai Sabilulungan dalam pemerintahannya tercermin dalam visi, misi, RPJMD, RKPD

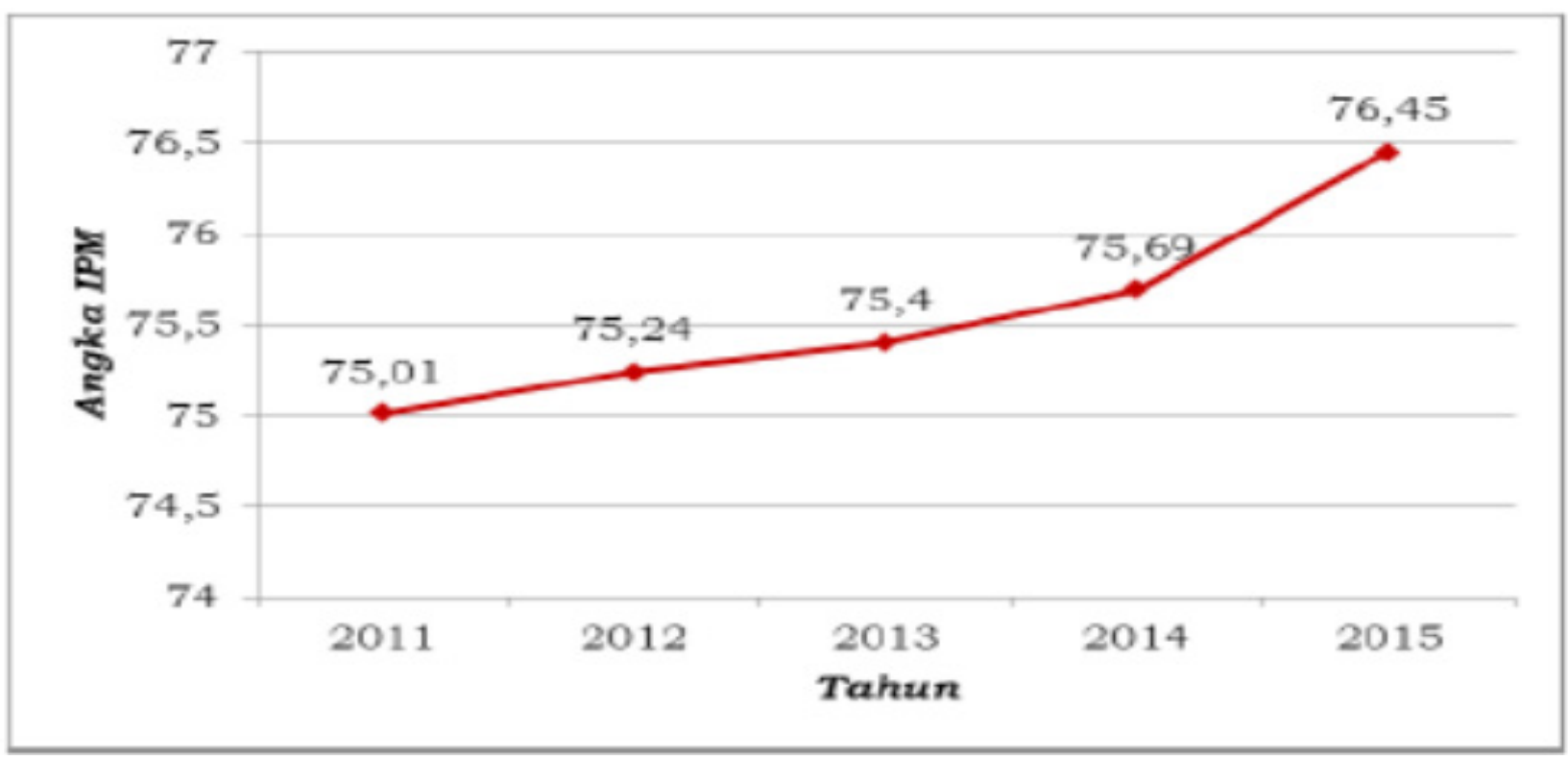

Sumber: Dokumen RPJMD Kabupaten Bandung Tahun 2016 - 2021

Gambar 1 Pencapaian IPM Kabupaten Bandung 
maupun dalam berbagai program-program pemerintahan.

Berbagai program di Kabupaten Bandung pun kerapkali menggunakan kata "Sabilulungan" seperti; Sabilulungan Raksa Desa, yang bertujuan membantu mengatasi segala permasalahan sosial di wilayah Kabupaten Bandung. Inti program tersebut adalah menjaga atau memelihara kondisi rumah, air bersih, kakus, sampah dan alam sekitar. Program yang digulirkan sejak awal Dadang Naser menjadi Kepala Daerah yaitu di tahun 2010 hingga saat ini.

Visi pemerintahan pada tahun 20162021, sebagaimana termuat dalam dokumen Rencana Pembangunan Jangka Menengah Daerah (RPJMD) Kabupaten Bandung Tahun 2016 - 2021 adalah, "Memantapkan Kabupaten Bandung yang Maju, Mandiri dan Berdaya Saing, melalui Tata Kelola Pemerintahan yang Baik dan Sinergi Pembangunan Perdesaan, Berlandaskan Religius, Kultural dan Berwawasan Lingkungan". Dalam Visi Pemerintah Kabupaten Bandung di atas, terkandung filosofi Sabilulungan dalam implementasinya. Seperti, tata kelola pemerintahan yang baik, dalam penjelasan pokok tersebut dikatakan bahwa kondisi penyelenggaraan pemerintahan Kabupaten Bandung yang dilakukan secara bersama- sama antara pemerintah, masyarakat dan swasta, dan bertanggungjawab, dengan menjaga sinergitas interaksi yang bersifat konstruktif diantara tiga dominan utama tersebut.

Hal itu dijelaskan Dadang Naser sebagaimana dikutip dalam soreangonline.com; "...dukungan dan keterlibatan seluruh stakholder pembangunan mulai pemerintah, masyarakat maupun kalangan usahawan. Ketiga kekuatan ini perlu bersinergi, bergandeng tangan dalam konsep Sabilulungan, agar roda pembangunan di Kabupaten Bandung berjalan sesuai dengan harapan..."

Rencana Kerja Pembangunan Daerah (RKPD) Kabupaten Bandung Tahun 2016 sebagai tindak lanjut dari Perbub Bandung No. 23 Tahun 2015 Tentang Rencana Kerja Pembangunan Daerah Kabupaten Bandung Tahun 2016. Pada awal dokumen RKPD tersebut tertulis tentang sasaran dan prioritas yang ingin dicapai, dalam rangka mewujudkan peningkatan kualitas pembangunan yang berwawasan lingkungan dan peningkatan perekonomian daerah yang berdaya saing dengan nilai-nilai (value) luhur "Sabilulungan", nilai-nilai ini dalam rangka mewujudkan sosok masa depan masyarakat Kabupaten Bandung 2025 "Repeh Rapih Kertaraharja".

Mengacu pada instrument komunikasi efektif menurut Tubb dan Moss (Alamsyah \& Fitriah, 2017) implementasi komunikasi efektif pada aktivitas komunikasi pelayanan publik melalui nilai Sabilulungan di Kabupaten Bandung masih belum dikatakan optimal, karena: Pertama, masih terdapat kesenjangan pemahaman mengenai konsep filosofi Sabilulungan yang menjadi spirit budaya organisasi yang dikembangkan. Artinya belum memenuhi instrument komunikasi efektif yakni tidakan penerima pesan belum sesuai dengan maksud pemberi pesan. Hal ini terlihat dari pernyataan Sugianto, salah seorang anggota DPRD Kabupaten Bandung bahwa:

"...makna Sabililungan yang tercermin dalam visi misi, diturunkan dalam program dan kegiatan baru mulai dapat diinternalisasikan kesetiap SKPD pada tahunketigaperiode pertamakepemimpinan Bupati, hingga saat ini..."

Kedua, perilaku seluruh pegawai belum sepenuhnya sesuai dengan konsep nilai sabilulungan yang digunakan sebagai budaya organisasi pemerintahan, hal tersebut tercermin dalam pernyataan Sugianto berikut: “..terjadi lokir jabatan dikarenakan dianggap tidak sesuai dengan konsep sabilulungan.."

Ketiga, aktivitas pelayanan publik seharusnya menunjukan sikap kerja secara profesional sesuai dengan nilai yang terkandung pada Sabilulungan; pekerja memiliki keahlian, atau menunjukkan kualitas kerja yang memenuhi standar profesi tertentu. Ukuran profesi itu dilihat dari proses penyelesaian dan tanggung jawabnya terhadap tingkat kualitas hasil, namun hal tersebut belum sepenuhnya dapat dikatakan optimal, mengingat hasil survei yang dilakukan Pusat Kajian dan Kepakaran Statistik (P2KS) Unpad atas Kepemimpinan Kepala Daerah di Jawa Barat Tahun 2015, menunjukan bahwa tingkat kepuasan masyarakat terhadap layanan publik oleh Pemkab Bandung yang meliputi enam aspek kinerja, yaitu infrastruktur, kepemimpinan, regulasi, pelayanan dasar, anggaran, dan sumber daya aparatur, Pemkab 
Bandung tidak termasuk dalam kategori 5 daerah dengan indeks kepuasan responden tertinggi, artinya masih banyak ketidakpuasaan masyarakat terhadap pelayanan publik di Pemkab Bandung.

Berbagai program, kegiatan maupun pemahaman baik di tingkat aparatur, masyarakat dan sektor swasta melalui implementasi nilai Sabilulungan menunjukkan kemajuan yang baik, namun masih belum optimal sebagaimana telah dipaparkan diatas, sehingga perlu pengkajian lebih mendalam terkait pemahaman stakeholder di Kabupaten Bandung tentang nilai "Sabilulungan" sebagai budaya organisasi pemerintahan.

Budaya organisasi memiliki pengaruh besar terhadap perilaku individu dalam organisasi. Semua individu dan kelompoknya bereaksi terhadap makna yang mereka hubungkan dengan berbagai kondisi-kondisi lingkungan, dan bertindak menurut persepsi mereka terhadap lingkungan mereka. Oleh karena itu penting memahami tatacara orang menggambarkan situasi mereka dalam menjelaskan tindakannya, persepsi dan definisi mereka, yang dipengaruhi oleh para aktor di sekitarnya.

Dalam sudut pandang konstruktivis sosial, individu memahami budaya organisasi sebagai entitas dinamis, sosial dan diskursif yang dibangun melalui keterlibatan dengan lingkungan sekitar. Budaya secara sosial dan diskursif dibangun melalui aktivitas dan interaksi individu yang berakar pada masyarakat, yang semuanya menafsirkan dan mengkonsumsi budaya secara berbeda. Realitas budaya adalah kenyataan yang dibangun secara sosial, yang dalam proses perubahan terusmenerus.

Berdasarkan latar belakang penelitian di atas, penelitian ini bertujuan untuk mengetahui Transformasi nilai Sabilulungan dalam aktivitas komunikasi pelayanan publik di Pemerintahan Kabupaten Bandung.

\section{METODE PENELITIAN}

Pendekatan penelitian ini adalah pendekatan kualitatif menggunakan metode studi kasus. Pendekatan kualitatif dengan melihat permasalahan sebagai satuan yang bulat dan menyeluruh (holistik), menghubungkan setiap variabel fungsional dan memahami hakekatnya, serta menyoroti tentang nilai "Sabilulungan sebagai kearifan lokal masyarakat Sunda yang dijadikan budaya organisasi pemerintahan di Kabupaten Bandung dalam kepemimpinan Dadang M. Naser sebagai Bupati.

Subjek penelitian dipilih secara purposif berdasarkan tingkat keterlibatan subjek pada peristiwa atau kasus yang diteliti untuk memperoleh kedalaman informasi yang diperlukan dalam penelitian ini.

Kriteria informan dalam penelitian ini, meliputi: (1) Pencetus ide dasar sabilulungan; (2) Aparatur pemerintah di Kabupaten Bandung sebagai pihak yang digerakan; (3) Masyarakat sebagai sasaran penerima layanan pemerintah; dan (4) Sektor swasta sebagai mitra pemerintah. Sehingga berdasarkan kriteria informan tersebut, objek penelitian dalam hal ini terkait bagaimana transformasi nilai kearifan lokal sabilulungan dalam aktivitas komunikasi pelayanan publik di Pemerintah Kabupaten Bandung pada kepemimpinan Dadang Naser.

Teknik pengumpulan data yang digunakan adalah wawancara mendalam, observasi, dokumentasi dan studi kepustakaan. Selanjutnya peneliti melakukan analisis data dimana analisis data dilakukan setelah data berupa transkrip hasil wawancara dan observasi, maupun gambar, foto, catatan harian subjek dan sebagainya dianggap lengkap dan sempurna. Peneliti sebagai instrumen kunci dalam dalam penelitian ini melakukan analsis data karena hanya peneliti sendiri yang mengetahui secara mendalam semua masalah yang diteliti.

Pengujian data yang dilakukan dalam penelitian ini meliputi uji Credibility (validitas internal), Transferability (validitas eksternal), Dependability (reliabilitas), dan Confirmability (obyektivitas).

\section{HASIL DAN PEMBAHASAN}

Sabilulungan berarti saling tolong menolong. Sabilulungan juga menjadi warisan lisan yang berasal dari bahasa Sunda asli. (Sumantri, 1985). Nilai Sabilulungan inilah yang dibawa oleh Dadang Naser kedalam penyelenggaraan pemerintahan di Kabupaten Bandung, pada periode beliau menjadi Bupati, sebagaimana diutarakan Dadang Naser berikut: “...Saya sedang mencoba memasukan Sabilulungan sebagai modal sosial untuk menggerakan Pemerintahan. Pemerintahan ya itu pelayanan publik, bagaimana 
meningkatkan kesejahteraan, bagaimana merapatkan kesenjangan menjadi kenyataan..."

Sabilulungan yang merupakan bagian dari kebudayaan Sunda, termasuk ke dalam identitas daerah yang menjadi bagian dari warisan generasi sebelumnya yang patut dilestarikan. Untuk itu perlunya integrasi antara pemerintah dan masyarakat dalam melestarikan nilai kearifan lokal (Ade \& Affandi, 2016).

Identitas sebuah daerah bergantung pada keberhasilan pembangunan yang membutuhkan kerjasama antar setiap sektor untuk mewujudkannya. (Perbawasari, Dida, \& Nugraha, 2019) Dengan nilai Sabilulungan, diharapkan dapat membantu pembangunan daerah salah satunya melalui aktivitas komunikasi pelayanan publik.

Nilai kearfikan lokal mengandung nilai moralitas yang secara langsung maupun tidak langsung dapat dijadikan semacam pedoman atau ukuran tindakan atau perbuatan masyarakat maupun elit penguasa dalam kehidupan (Mariana \& Paskarina, 2009). Nilai kearifan lokal juga dapat menjadi sarana komunikasi yang efektif untuk mewujudkan kesejahteraan masyarakat mengingat dinamika kebudayaan akan terus berkembang sehingga nilai kearifan lokal bisa dijadikan dasar dalam membangun masyarakat (Kumianto, 2016).

Fungsi nilai kearifan lokal yang bisa menjadi sarana komunikasi dalam membangun masyarakat, memiliki kesamaan konsep dengan fungsi lembaga Pemerintah dalam melakuakan pelayanan publik yakni bertujuan untuk mencapai kesejahteraan masyarakat. Salah satu transformasi nilai kearifan lokal Sabilulungan diterapkan pada tradisi lisan yang erat kaitannya dengan aktivitas komunikasi.

Berbagai praktek, representasi, ekspresi, pengetahuan, keterampilan: serta instrumentinstrumen, obyek, artefak danlingkungan budaya yang terkait meliputi berbagai komunitas, kelompok, dan dalam beberapa hal tertentu, perseorangan yang diakui sebagai bagian warisan budaya mereka. Warisan budaya tak benda ini, diwariskan dari generasi ke generasi, secara terus-menerus diciptakan kembali oleh berbagai komunitas dan kelompok sebagai tanggapan mereka terhadap lingkungannya, interaksi mereka dengan alam, serta sejarahnya, dan memberikan mereka makna jati diri dan keberlanjutan, untuk memajukan penghormatan keanekaragaman budaya dan kreatifitas manusia.

Perwujudannya antara lain di bidangbidang sebagai berikut: (1) Tradisi dan ekspresi lisan, termasuk bahasa sebagai wahana warisan budaya takbenda; (2) Seni pertunjukan; (3) Adat istiadat masyarakat, ritus, dan perayaanperayaan; (4) Pengetahuan dan kebiasaan perilaku mengenai alam dan semesta; serta (5) kemahiran kerajinan tradisional.

Nilai Sabilulungan sebagai tradisi yang telah lama ada pada kehidupan masyarakat Sunda sejak dahulu diakui oleh Dadang Naser , bahwa:

".. Sabilulungan berasal dari Ki Sunda yang sudah ada sejak zaman Belanda. Sabilulungan sabilulungan merupakan nilai atau karakter lokal yang hidup, tumbuh dan berkembang di masyarakat sunda..."

Berdasarkan pendapat di atas, Sabilulungan sebagai tradisi lisan masyarakat Sunda yang mengandung nilai kearifan lokal Sunda. Pengertian kearifan lokal dalam berbagai referensi dikatakan sebagai nilai-nilai yang berlaku dalam suatu masyarakat, diyakini kebenarannya dan menjadi acuan dalam bertingkah-laku sehari-hari masyarakat setempat. Menurut (Isnendes, 2014), kearifan lokal ini bersifat abstrak sekaligus juga kongkret. Pedoman-pedomannya berupa sistem yang abstrak, tetapi dalam pelaksanaannya berupa sistem yang kongkret karena menjadi alat yang digunakan dalam memperbaiki dan menyelesaikan permasalahan dalam masyarakat budaya.

Pemahaman akan tradisi lisan tidak hanya berkisar pemberian suatu ruang agar tradisi tersebut bisa digelar, tetapi secara tekstual dan kontekstual, tradisi lisan tersebut juga harus dipahami. Tujuannya adalah agar nilai yang melekat dalam tradisi lisan tersebut bisa dipahami oleh masyarakat pada setiap jamannya.

Upaya memahami nilai Sabilulungan agar tetap relevan dengan konteks kekinian, salah satunya dengan melakukan inovasi terhadap makna-makna yang terkandung di dalamnya, sebagaimana dilakukan oleh Dadang Naser dengan berinovasi memaknai nilai Sabilulungan melalui akronim. Akronim Sabilulungan menurut Dadang Naser, adalah: "SA" nya 


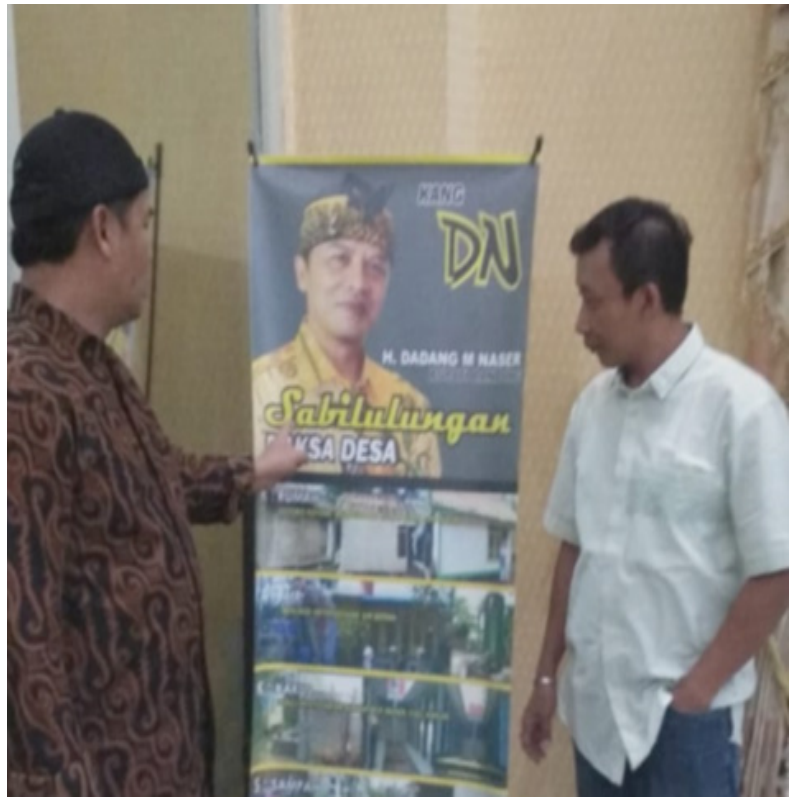

Sumber : Hasil Penelitian, 2017

Gambar 2 Gambar Tulisan Sabilulungan

Sabar, "BI" nya Bijak, "LU" nya luhung, "LU" nya luhur, "NGAN" nya Ngancik.

Selain berinovasi dengan memberikan akronim, Dadang Naser juga berinovasi dengan memberikan simbol gambar Sabilulungan berupa aksara yang dirangkai, berikut penjelasannya:

“...Ya saya yang nulis saya yang gambar. Tapi saya gambar ini Sabilulungan harus berangkai, aksarana kudu nempel. Nanti kan dalam Sabilulungan dikatakan Akur jeng dulur, panceg dina galur. Itu aplikasi Sabilulungan, harus dijaga..."

Lebih lanjut Dadang Naser menjelaskan:

"...Gotong royong dalam Ki Sunda mah bagian dari Sabilulungan. Sabilulungan, dasar gotong royong. Jadi, Sabilulungan mah bukan gotong royong saja. Tapi, sinergitas, kebersamaan, silih asah, silih asih dan silih asuh itu bagian dari Sabilulungan. Silih pikaheman, terus ngaluluguan, jadi ngakojoan, itu kepemimpinan. Jadi, memberikan keteladanan di Sabilulungan itu, jadi ada spiritualnya..."

Kemudian nilai Sabilulungan dapat diketahui lebih mendalam melalui analisis makna dalam lirik lagu Sabilulungan. Lirik lagu Sabilulungan karya Mang Koko tersebut juga menjadi inspirasi bagi Dadang Naser mengembangkan makna Sabilulungan dalam konteks kekinian, menurut Dadang Naser:

“...Jadi, hirup Sabilulungan, genteng ulah potong, sifatsilihrojong, persatuan tembong jeung Gotong Royong. Itu maknanya setara dengan nilai filsafat bangsa, jati diri bangsa, Pancasila, Bhineka tunggal itu ada perbedaan-perbedaannya, tapi satu untuk kejayaan Indonesia. Bhinneka Tunggal Ika di breakdown oleh Pancasila. Pancasila menurut founding father nya Bung Karno disampaikan bisa diperah menjadi Trisila, kalau bahasa saya memahamkan Pancasila itu Trisila, Ketuhanan, Keamanusiaan...”

Menggali makna nilai Sabilulungan yang terkandung dalam lirik lagu Sabilulungan karya Mang Koko, dilakukan peneliti dengan mewawancarai Dr. Lili Suparli, M. Sn., yang menjabat sebagai Ketua Program Studi Karawitan Fakultas Seni Pertunjukan (FSP) Institut Seni Budaya Indonesia (ISBI) Bandung. Menurut Lili Suparli, untuk menjelaskan makna lirik dalam sebuah lagu, dalam konteks sastra lagu terdapat beberapa model, misalkan seperti menulis, dimana dilakukan pembahasan dulu baru kemudian disimpulkan, yang disebut kata kunci. Terdapat juga model bait pertama yang diperjelas dalam bait kedua, atau juga penjelasan yang disimpulkan dalam bait berikutnya. Bisa juga dalam memaknai lagu, dari sekian bait dalam sebuah lagu, ragam bait per bait bisa berbeda pembahasannya, tapi bisa juga berkaitan bahasannya, dimana bait satu dibahas oleh bait dua, atau oleh bait ketiganya, dan seterusnya.

Terkait lagu Sabilulungan, menurut Lili Suparli, terdapat 4 bait dengan 2 pengulangan, dimana bait ketiga merupakan pengulangan bait pertama dan bait keempat pengulangan dari bait pertama. Pengulangan disini lebih pada pengulangan melodi atau nada lagunya, bukan pada maknanya, sedangkan pada maknanya sendiri lebih menjelaskan atau menjabarkan sebab Sabilulungan. Menurut Lili Suparli :

“...Nah, Sabilulungan mah ieu teh kan dua pengulangan, aya bait kahiji sareng bait kadua. Teras bait katilu jeung bait kaopat teh. Teras bait katilu teh pengulangan tina bait kahiji, bait kaopat pengulangan bait kadua. Tapi secara prinsip ieu teh saling ngajelaskeun, bait kadua ngajelaskeun bait katilu. Maknanya mah hampir sama, ngan 
pengulangan didinya teh pengulangan lagu, melodi lagu nya nada lagu. Secara prinsipna mah upami tinu ieu mah penjelasan makna ti nu lebih ngajabarkeun sebab Sabilulungan teh bakal kieu bakal kieu, nah itu..."

Selengkapnya makna lirik dalam lagu Sabilulungan menurut Lili Suparli, sebagai berikut:

"...lirik nu kahiji "Sabilulungan dasar gotong royong" hartosna anungajagjageun landasan atawa nu jadi landasan kalaksana gotong royong teh ayana di Sabilulungan. Ieu kan konotasi pemaknaan dari kalimat itu saja sudah menunjukkan bahwa Sabilulungan itu hal yang berbeda. Landasaran berpikir, landasan berprinsip untuk mencoba ke gotong royong teh nya Sabilulungan, matak disebatkeun Sabilulungan dasar gotong royong..."

Dijelaskan lebih lanjut terkait makna lirik pertama:

“...Dina konotasi pemaknaan dari kalimat itu saja Sabilulungan adalah sebuah pemaknaan yang berbeda, lebih berprinsip. Jadi lamun henteu mah landasan berpikir gotong royong teh Sabilulungan. Matak tadi babasan samiuk Sabilulungan. Samiuk Sabilulungan teh nyaeta upami dimaknai dina babasan eta mah ngahijikeun rasa. Samiuk Sabilulungan, jadi ngahijikeun dua rasa. Nah, gotong royong mah akibat engke..."

Lirik kedua menurut Lili Suparli:

"...Sabilulungan sifat silih rojong. Lain saukur saling bantu hungkul silih rojong mah, tapi bisa saling ngabantu, saling dukung atawa saling support ka ayunkeun. Bisa silih sebab, bisa silih motivasi..."

Penjelasan untuk lirik ketiga menurut Lili Suparli: “...Sabilulungan genteng ulah potong. Sabilulungan sifat geus kuat janten urang geus genteng gek ulah nepi ka potong..."

Makna genteng, lebih luar dijelaskan Lili Suparli, sebagai berikut:

"...Genteng ulah potong teh anu kalo pun ada masalah yang pelik tapi jangan sampai putus. Genteng teh kieu upami urang arek ulin tah aya tapak ukur genteng kitu. Tapak- tapak, tah dianalogikeunna urang Sunda teh ulah nepi ka cacat ulah nepi kapotong. Da lamun dina atap bumi eta mah sanes genteng tapi kenteng. Ari genteng teh kieu, upami urang arek aya urang lembur eweuh nanaon, mungkin itu tina akibat jadi si sampean teh genteng atawa pananganna. Genteng-genteng ulah potong, hartosna sanajan genteng ari bahasa urang mah cacat pan? Tapi, urang mah tetep genteng ulah potong. Jadi, nanaon teh kitu, atau atanapi tingali tatangkalan oge sok dianggo pamoen oge dibengkeut ku kawat. Tah, eta teh genteng ulah potong, sanajan dibengkeut ku kawat oge tapi teu potong nya. Dina lirik itu genteng ulah potong itu ada kekurangan tapi tidak menunjukkan hal yang perpecahan. Potong disana menunjukkan makna kekurangan, sanajan aya kekurangan menimpa apapun jangan sampe terjadi perpecahan..."

Penjelasan lirik keempat dalam bait pertama, di sampaikan Lili Suparli sebagai berikut:

"...Sabilulungan persatuan tembong. Lamun Sabilulungan tos aya maka didinya bakal ngahiji persatuan, kakarek moal matak gotong royong teh pan pinuh persatuan. Nah, ieu mah berarti Sabilulungan mah landasan berpikir, landasan awal pikeun terjadinya gotong royong, pikeun terjadinya engke motivasi silih rojongna oge sifat-sifat anu kakuatankakuatan sejenna ulah nepi ka potong..."

Melanjutkan penjelasan pada lirik lagu Sabilulungan, bait kedua. Lirik pertama dan kedua pada bait kedua dijelaskan sebagai berikut:

“...Tohaga rohaka. Teguh tangguh perbawa sabilulungan. Nah, tohaga rohaka itu kan luar biasa siga tekur weh lah, tapi rohaka dina bahasa Sunda mah. Eta ngagambarkeun lamun ngalakukeun Sabilulungan. Jadi rohaka itu perbawana Sabilulungan, samiuk Sabilulungan. $K u$ kadang ngajikeunna urang boga motivasi mah tah ieu. Dampak dari Sabilulungan, jadi janten perbawa mah tiasa makna na akibat. Akibatnya, tohaga rokaha mah besar. Kekuatan yang besar, tohaga itu kuat, rohaka itu besar, rongkah..." 
Sadia Sajiwa

“...Segut singkil ngabasmi pasalingsingan. Tah, segut singkil, segut teh artina semangat ulet segut teh. Jadi contoh tah kieu "Duh segut dahar eta budak nyah" enerjik didinya mah lebih kana enerjik. Tah, heeum singkil teh dia berani, singkil dia berani siap-siap sudah bertekad. Nah, ngabasmi pasalingsingan, ari ngabasmi pasalingsingan teh dina kecap, upami pasalingsingan hungkul mah kieu kecapna "akang bade kadieu, abdi bade kahandap, pasalingsingan" berbeda ari janten mah ngabasmi teh ulah terjadi perbedaan. Terjadinya konflik itu kan akibat jika ada perbedaan. Jadi, mun didieu mah perbedaan paham, perbedaan tujuan, perbedaan kahayang anu leuwih ieu persoalan kunaon Sabilulungan teh tah landasanna. Landasan pikeun ulah terjadi pasalingsingan, perbedaan paham. Kan perbedaan paham itu didieu teh dimaknai pasalingsingan teh perbedaan paham, perbedaan tujuan, perbedaan kahayang..."

Penjelasan dilanjutkan pada bait ketiga, secara berurutan dijelaskan oleh Lili Suparli, sebagai berikut:

"...Sabilulungan hirup sauyunan. Tah, lamun tos terjadi Sabilulungan tina rasa pasti bakal hirupna sauyunan. Rukun sauyunan silih ayunkeun silih anter artina mah ngahiji-ngahiji keneh. Duh, eta sauyunan sareng adina, artina teh silih asih sauyunan. Harmoni..."

“...Sabilulungan silih pikaheman. Ari silih pikaheman teh ngaos heman rasa, rasa untuk kasih sayang..."

“...Sabilulungan tulung tinulungan. Ari tulung tilulungan teh eta mah kecap pretekan ti silih tulung. Saling menolong, jadi tah nu tadi lamun tos aya dasarna mah. Arek silih tulungan, silih naon deui ge tiasa..."

“...Sabilulungan kukuh persatuan. Jelas, Sabilulungan kukuh persatuan. Tengkuh, kokoh menguatkan, kukuh teh memegang prinsip bukan kekuatannya terhadap prinsip. Bukan kokoh tapi keukeuh, kukuh teh leuwih kuat tina kokoh. Janten tengkuh, lamun ceuk ieu na mah kuat megang prinsipna. Si eta mah kukuh weh kana elmu eta na. Jadi kukuh pageuh..."

Selanjutnya bait terakhir atau keempat, secara berurutan dijelaskan oleh Lili Suparli, sebagai berikut:

"...Santosa Samakta. Santosa mah kan hirup. Lamun samakta mah leuwih ka persoalannana dia siap segalana samakta. Dia siap dengan berbagai hal, karena apa santosa еeuи karena dia memiliki berbagai hal ceuk eta mah sejahtera dengan kekuatan-kekuatan tadi. Jadi samakta teh santos kieu, upami prajurit disebatkeun samakta teh janten kieu siap dengan atau siap kuat dengan apapun. Siap tempur, sudah samakta. Tos samakta..."

"...Teuneung ludeung ngajaring kawibawaan. Tadi didinya tah nembe jadi teneung ludeung teh dia sudah berani mau kemana pun. Teneung ludeung, ngajaring kawibawaan. Jadi, tah ngajaring disini teh dia sudah ngabawa ngapit kawibawaan..."

"...Saihwan Safaham. Satu barisan saihwan teh sapamaneugan..."

“...Nagri nanjung berekah sabilulungan. Tadi upami tos ngalukeun ieu ieu nu tadi teh sadayana, tah nagri teh bakal narima teh kunaon, berkah tina Sabilulungan..."

"Nah, kieu pada prinsipna kan konsep penjelasan teh tiasa ngajelaskeun kata kunci ieu jeung ieu. Ngajelaskeun teh tiasa ngabedah hasil ieu tinu ieu, misalkeun ieu Sabilulungan hirup sauyunan, santosa samakta. Kan penjelasanna lamun tos hirup sauyunan pasti santosa trus bakal kajaring kawibawaan nanjung nagri berkah Sabilulungan."

Selain adanya inovasi berupa akronim dan simbol Sabilulungan, transformasi nilai Sabilulungan dapat dilihat pada aktivitas komunikasi pelayanan publik melalui media sosial dengan menyisipkan sapaan "Wargi Sabilulungan" pada setiap postingan di akun media sosial sehingga komunikasi pelayanan publik akan lebih dapat diterima oleh masyarakat 


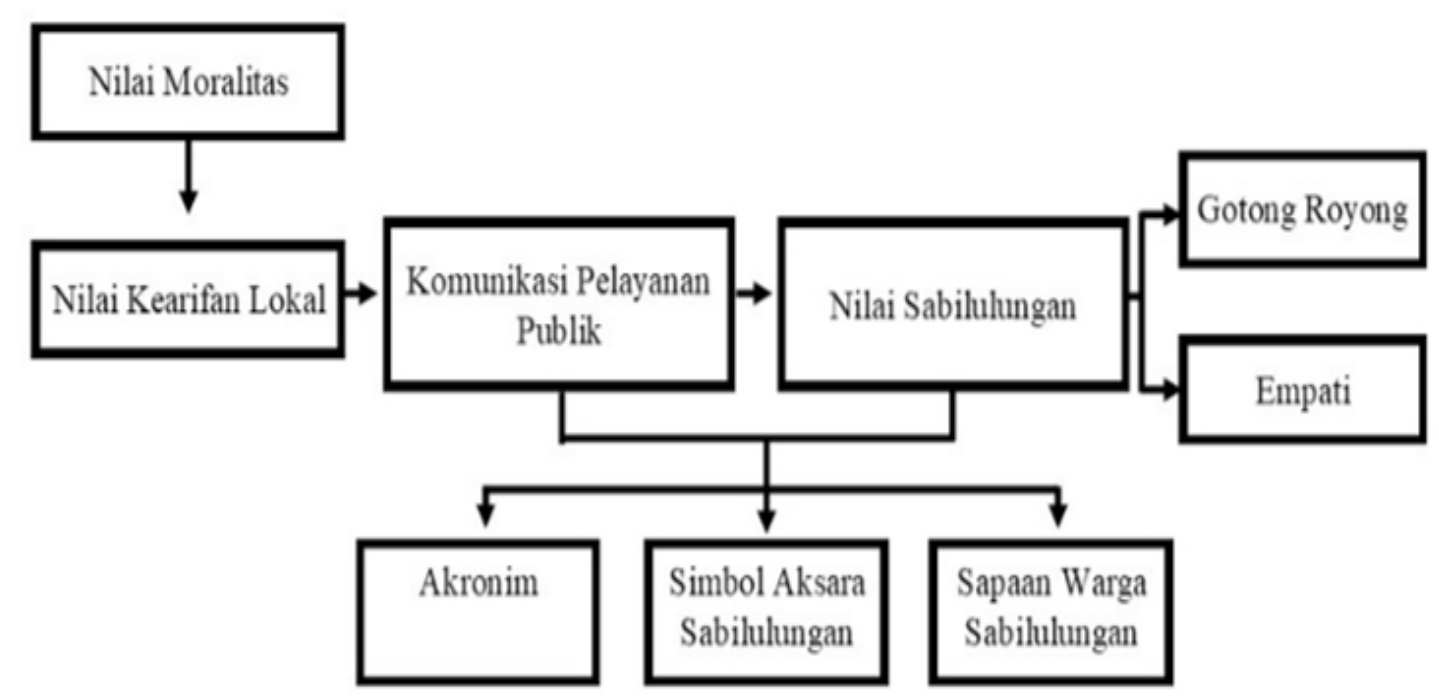

Sumber: Hasil Penelitian, 2017

Gambar 3 Transformasi nilai kearifan lokal sabilulungan dalam aktivitas komunikasi pelayanan publik di Pemerintah Kabupaten Bandung

sekaligus turut mengkomunikasikan nilai Sabilulungan pada masyarakat luas.

Transformasi nilai kearifan lokal sabilulungan dalam aktivitas komunikasi pelayanan publik di Pemerintah Kabupaten Bandung sudah sesuai mengingat karakteristik masyarakat wilayah Kabupaten Bandung. Berdasarkan hasil penelitian yang dilakukan oleh (Nekroma, 2017) adanya implementasi nilai kearifan lokal pada pelaksanaan fungsi lembaga pemerintah dapat membantu aparatur pemerintah untuk melakukan tugas sesuai dengan kewajibannya.

Nilai kearifan lokal dapat menjaga hubungan berbasis budaya (Hidayat \& Hafiar, 2019). Sehingga hubungan antara publik dan pemerintah dapat terjalin dengan baik melalui transformasi nilai kearifan lokal Sabilulungan dalam aktivitas komunikasi pelayanan publik di Pemerintah Kabupaten Bandung.

Pelayanan publik sangat krusial dalam aktivitas pemerintah. Hal ini seperti dijelaskan dalam penelitian yang dilakukan oleh (Rahman \& Sjoraida, 2017) jika kebutuhan publik dapat terpenuhi melalui upaya pelayanan publik, sehingga publik akan mengharapkan adanya pelayanan yang optimal dari pemerintah.

Selain itu, aparatur pemerintah memiliki cara yang baik dalam pelayanan publik yakni dengan sikap yang ramah sehingga kepuasan masyarakat terhadap kinerja lembaga
Pemerintah sangat tinggi. Hasil penelitian ini dapat dijadikan acuan jika nilai kearifan lokal dapat ditransformasikan pada aktivitas komunikasi pelayanan publik yang pada akhirnya meningkatkan kinerja lembaga Pemerintah.

Implementasi nilai sabilulungan pada elemen pemerintahan Kabupaten Bandung sudah dijalankan dengan baik seperti adanya inovasi berupa akronim, simbol gambar, dan sapaan khusus Sabiliulungan dilakukan agar lebih mudah dipahami oleh stakeholder. Akronim Sabilulungan dirasa sudah tepat untuk dijadikan landasan pelayanan publik karena setiap penggalan katanya dapat menjadi landasan dalam berkomunikasi utamanya dalam pelayanan publik yang mengutamakan hubungan timbal balik yang efektif.

Namun pada pelaksanaannya belum optimal karena salah satunya perilaku seluruh pegawai belum sepenuhnya sesuai dengan konsep nilai Sabilulungan yang digunakan sebagai budaya organisasi pemerintahan. Padahal nilai budaya kearifan lokal dalam hal ini Sabilulungan dapat menunjang aktivitas komunikasi pelayanan publik dalam hal ini melalui budaya organisasi di Pemerintah Kabupaten Bandung.

Nilai kearifan lokal Sabilulungan sebaiknya dapat dioptimalkan dalam aktivitas komunikasi pelayanan publik. Dalam hasil penelitian yang dilakukan oleh (Parera, Mingkid, \& 
Rembang, 2014) dijelaskan jika aktivitas organisasi dapat ditunjang dengan baik melalui komunikasi, sebab jika aktivitas komunikasi dapat diselenggarakan dengan baik maka akan menunjang dikerja organisasi. Selain itu ditemukan aspek dalam pelayanan publik yang harus dipenuhi oleh sebuah lembaga adalah adanya rasa empati serta cepat tanggap dalam melihat kebutuhan publik. Hal ini dapat terselenggara dengan optimal jika seluruh stakeholders menerapkan nilai Sabilulungan dimana adanya rasa kebersamaan dan sinergitas yang tinggi sehingga transformasi nilai kearifan lokal Sabilulungan sudah tepat untuk dijadikan landasan dalam aktivitas komunikasi pelayanan publik.

Nilai Sabilulungan sebagai tradisi masyarakat Sunda yang memiliki nilai-nilai filosofis untuk membangun karakter, dianggap sebagai modal sosial yang dibawa ke dalam penyelenggaraan pemerintahan, khususnya pelayanan publik di Kabupaten Bandung oleh Dadang Naser sebagai Bupati, sebagaimana diutarakan oleh Dadang Naser :

"...Saya sedang mencoba memasukan Sabilulungan sebagai modal sosial untuk menggerakan Pemerintahan. Pemerintahan ya itu pelayanan publik, bagaimana meningkatkan kesejahteraan, bagaimana merapatkan kesenjangan menjadi kenyataan..."

Transformasi nilai Sabilulungan bisa dioptimalkan melalui penggunaan media sosial. Partisipasi masyarakat dapat meningkat dengan dibukanya sistem ICT pada aktivitas komunikasi pelayanan publik. Keluhan dan aspirasi publik akan dengan mudah disampaikan pada Lembaga Pemerintah. (Supardal, 2016). Sejalan dengan pernyataan tersebut, Penelitian yang dilakukan oleh (Rahadi, 2007)yang terdiri dari 3 variabel utama, yaitu manfaat dirasakan (usefulness membuktikan jika kemajuan teknologi dapat digunakan untuk mengoptimalkan pelayanan publik oleh Pemerintah.

Membawa nilai Sabilulungan kedalam ruang-ruang pemerintahan, tentu bukan persoalan mudah. Pemerintahan selama ini dianggap anggap kaku, birokratis akibat persoalan struktural, kedudukan ataupun hirarki. Sebaiknya transformasi nilai kearifan lokal seperti Sabilulungan dilakukan melalui berbagai upaya yang melibatkan seluruh aspek masyarakat (Ulandari, 2014). Sedangkan nilai Sabilulungan dianggap fleksibel, dalam konteks ini bukan berarti nilai Sabilulungan menjadikan hirarki antara atasan dan bawahan menjadi lebur. Akan tetapi menurut lili hambali, bagaimana prinsip nilai Sabilulungan dipegang oleh seorang Bupati, oleh seorang Wakil Bupati, oleh rakyat itu dijatahkan sesuai dengan fungsi strukturalnya.

\section{SIMPULAN}

Pemilihan nilai kearifan lokal yang ditransformasi pada aktivitas komunikasi pelayanan publik salah satunya didasari oleh nilai moralitas yang terdapat pada nilai kearifan lokal. Nilai moralitas tersebut dapat menjadi pedoman dalam melakukan tindakan. Sabilulungan berusaha ditransformasi oleh Pemerintah Kabupaten Bandung. Sabilulungan bermakna gotong royong dan saling tolongmenolong. Inti dari nilai Sabilulungan dapat dijadikan landasan dalam melakukan komunikasi pelayanan publik. Dimana dalam melakukan pelayanan publik, aspek yang harus diperhatikan adalah adanya rasa empati juga cepat tanggap dalam melihat suatu keadaan publik. Hal ini dapat dicapai dengan sinergitas yang tinggi yang ditransformasi dari nilai Sabilulungan.

Implementasi nilai Sabilulungan dibuat dalam bentuk inovasi berupa akronim, simbol sabilulungan dan sapaan bagi masyarakat pada setiap pengkomunikasian aktivitas pelayanan publik. Berbagai inovasi yang dilakukan sudah berlangsung dengan baik namun belum sepenuhnya optimal sebab jika dilihat dari perilaku pelaksana program belum memahami dan menerapkan prinsip-prinsip Sabilulungan.

Peneliti menyarankan transformasi nilai kearifan lokal dapat dilakukan lebih optimal salah satunya dengan melalukan integrasi media dalam aktivitas pelayanan publiknya sehingga diharapkan partisipasi masyarakat dapat meningkat, kinerja lembaga pemerintah juga mengalami peningkatan dan dapat terwujud tujuan dari pelayanan publik yakni tercapainya kesejahteraan masyarakat.

\section{DAFTAR PUSTAKA}

Ade, V., \& Affandi, I. (2016). Impementasi nilainilai kearifan lokal dalam mengembangkan 
keterampilan kewarganegaraan. Jurnal Pendidikan Ilmu Sosial, 25(1), 77-91.

Adha, M. M. (2015). Understanding the relationship between kindness and gotong royong for Indonesian citizens in developing bhinneka tunggal ika. In Sapriya, E. Kurniawan, \& S. Nurbayani (Eds.), The commemorative academic conference for the 60 anniversary of the 1955 Asian African Conference in Bandung, Indonesia. Bandung: School of Post-graduate Studies, Universitas Pendidikan Indonesia.

Alamsyah, A., \& Fitriah, M. (2017). Strategi komunikasi pelayanan publik melalui program pos pemberdayaan keluarga. Jurnal ASPIKOM, 3(2), 225-238.

Bachrein, S. (2010). Pendekatan desa membangun di Jawa Barat: strategi dan kebijakan pembangunan perdesaan. Analisis Kebijakan Pertanian, 8(2), 133149.

Budi, R. (2012). Komunikasi efektif dalam meningkatkan kualitas pelayanan publik. stimuli edisi IV. Retrieved from https://www.researchgate.net/ publication/330579081_Komunikasi_ Efektif_Dalam_Meningkatkan_Kualitas Pelayanan_Publik

Drajat, M. S. (2008). Pelayanan publik pada sektor komunikasi. Mediator: Jurnal Komunikasi, 9(56), 63-76.

Guntari, G. T. P. (2016). Adaptabilitas masyarakat Adat Kampung Naga sebagai Kampung Wisata Budaya. Student Universitas Negeri Yogyakarta, 5(9), 1-9.

Hidayat, D., \& Hafiar, H. (2019). Nilai-nilai budaya soméah pada perilaku komunikasi masyarakat Suku Sunda. Jurnal Kajian Komunikasi, 7(1), $84 . \quad$ https://doi. org/10.24198/jkk.v7i1.19595

Indrawardana, I. (2012). Kearifan lokal adat masyarakat Sunda dalam hubungan dengan lingkungan alam. Komunitas, 4(1), 1-8.

Isnendes, R. (2014). Estetika Sunda sebagai bentuk kearifan lokal masyarakat sunda tradisional dalam sawangan pendidikan karakter. Jurnal Ilmu Pendidikan Dan Pengajaran, 1(2), 194-206.

Kumianto, R. (2016). Kearifan lokal sebagai media unggul komunikasi membangun peradaban unggul. Artikel Semnas FISIP, 1-11. Retrieved from http://eprints.umpo.
ac.id/2969/1/Artikel Semnas FISIP.pdf

Sumantri, M (1985). Kamus Sunda-Indonesia. Retrieved from https://www.worldcat. org/title/kamus-sunda-indonesia/ oclc/14072218

Mariana, D., \& Paskarina, C. (2009). Kebangkitan lokal menjawab tantangan globalisasi : revitalisasi nilai-nilai budaya sunda bagi penciptaan local good governance di Jawa Barat.

Nekroma. (2017). Implementasi nilai budaya kearifan lokal Lampung dalam penyelenggaraan pemerintah desa. Universitas Lampung.

Parera, S. A., Mingkid, E., \& Rembang, M. (2014). Peran komunikasi organisasi dalam pelayanan publik di pt. taspen (persero) cabang Manado. Jurnal Acta Diurna, 3(3), 3-8. Retrieved from https://media.neliti. com/media/publications/90307-ID-perankomunikasi-organisasi-dalam-pelaya.pdf

Perbawasari, S., Dida, S., \& Nugraha, R. (2019). Peran stakeholders dalam membangun identitas Purwakarta yang berwawasan nilai budaya lokal. PRofesi Humas, 4(1), 23-46.

Rahadi, D. D. R. (2007). Peranan teknologi informasi dalam peningkatan pelayanan di sektor publik. Seminar Nasional Teknologi 2007 (SNT 2007).

Rahman, A., \& Sjoraida, D. F. (2017). Strategi komunikasi pemerintah Kabupaten Subang menyosialisasikan gerakan pembangunan untuk rakyat infrastruktur berkelanjutan. Jurnal Kajian Komunikasi, 5(2), 136. https://doi.org/10.24198/jkk.v5i2.8443

Rahmatiani, L. (2016). Nilai kearifan lokal sunda sebagai basis tata kelola pemerintahan yang baik (good governance). Civics, 1(1), 81-88. https://doi.org/ISSN 2527-9742

Robbins, S. P., \& Judge, T. A. (2017). Organizational behavior (17th ed.). London: Pearson Education Limited.

Schein, E. H. (2010). Organizational culture and leadership (4th ed.). San Fransisco: Jossey-Bass.

Supardal.(2016). Penerapan ict dalam pelayanan publik di Kabupaten Bantul. Jurnal Ilmu Pemerintahan: Otoritas, 6(2), 120-134. https://doi.org/e-ISSN: 2502-9320

Supriyadi, D., Nassarudin, E. H., \& Azhar, I. A. (2017). Sabilulungan untuk 
negeri (revitalisasi, internalisasi dan implementasi). Bandung: Bidang Kebudayaan Dinas Pariwisata dan
Kebudayaan Kabupaten Bandung. Ulandari, D. (2014). Penerapan nilai-nilai kearifan lokal dalam kehidupan masyarakat 